\title{
Demografik Özellikler Açısından Çalışanların Duygusal Zeka Düzeylerinin Turizm İşletmelerinde İncelenmesi (Examination of Emotional Intelligence Levels in Terms of Demographic Characteristics of Employees in Tourism Establishments)
}

\section{Halise Dilek SEVIN iD a Akyay UYGUR iD b M. Bahadır KOYUNCU iD c \\ a Ankara Hacı Bayram Veli Üniversitesi, Turizm Fakültesï, Rekreasyon Yönetimi Bölümü, Ankara, Türkiye. halise.sevin@hbv.edu.tr b Ankara Hacı Bayram Veli Üniversitesi, Turizm Fakültesï, Rekreasyon Yönetimi Bölümü, Ankara, Türkiye. akyay.uygur@hbv.edu.tr c Amasya IMKB Mesleki ve Teknik Anadolu Lisesi, Amasya, Türkiye. muratbahadırkoyuncu@windowslive.com}

\begin{tabular}{l} 
MAKALE BİLGÍsi \\
\hline Anahtar Kelimeler: \\
Turizm Çalışanları \\
Konaklama İşletmeleri \\
Duygusal Zeka(EI) \\
Gönderilme Tarihi 27 \\
Nisan 2020 \\
Revizyon Tarihi 8 A ğustos \\
2020
\end{tabular}

Kabul Tarihi 10 Eylül 2020

Makale Kategorisi: Araştırma Makalesi

\section{ÖZET}

Amaç - Müşteri istek ve beklentilerinin doğru şekilde anlaşılması ve zamanında karşılanması hizmet sağlayıcının teknik becerisi yanında, duygusal yeteneği ile de ilişkilidir. Müşteri memnuniyeti, çalışanlar arasında doğru iletişimin sağlanması, çatışmaların azaltılmasında duygusal zekanın önemli bir yeri vardır. $\mathrm{Bu}$ araştırmanın amacı turizm işletmelerinden biri olan otel çalışanlarının duygusal zeka düzeylerinin demografik özelliklere göre incelenmesi olup, duygusal zeka düzeyinin demografik özelliklere göre farklılık gösterip göstermediğinin tespit edilmesidir.

Yöntem - Antalya ilinde yer alan beş yıldızlı otellerde çalışanlar araştırmanın evrenini oluşturmaktadır. Analiz, ankete cevap veren otellerin farklı departmanlarda çalışan 583 kişi üzerinden değerlendirmeye alınmış, demografik özelliklere göre farklılık gösterme durumu parametrik olan test tekniklerinden $\mathrm{t}$ ve ANOVA testleri ile analiz edilmiştir. ANOVA testinde fark çıkması durumunda ikili fark için Tukey testi kullanılmıştır.

Bulgular - Demografik özelliklerden, cinsiyet, medeni durum, öğrenim durumu, aylık gelir, ailenin toplam geliri, uyruğun Türk veya yabancı olması, çocukluğun geçirdiği yerin farklı olması, mesleğin seçimi ile duygusal zeka boyutları açısından istatistiksel olarak anlamlı farklılık bulunamamıştır. Duygusal zeka düzeyi ile çalışanın statüsü, işletmede çalışma süresi, çalışılan bölüm açısından farklılık bulunmuştur.

Tartışma - Turizm işletmelerinden otel çalışanları üzerinde gerçekleştirlen bu çalışmada çalışanların statüleri arttıkça duygusal zeka puanlarının arttı̆̆ı görülmüş. Bu araştırmanın sonucu genellenebilir olmamakla birlikte, alana katkı sağlayacağı düşünülmektedir.

\begin{tabular}{l}
\hline ARTICLE INFO \\
\hline Keywords: \\
Tourism workers \\
Accommodation \\
Businesses \\
Emotional Intelligence \\
Received 27 April 2020 \\
Revised 8 August 2020 \\
Accepted 10 September \\
2020
\end{tabular}

Article Classification:

Research Article

\section{ABSTRACT}

Purpose - Correct understanding of customer demands and expectations and meeting them in a timely manner are not only associated with the service provider's technical skills but also their emotional ability. In addition to customer satisfaction, emotional intelligence also has an important role in terms of ensuring correct communication between employees and reducing conflicts. The aim of this study is to examine the emotional intelligence levels of hotel employees, one of the tourism enterprises, according to demographic characteristics, and to determine whether the level of emotional intelligence varies according to demographic characteristics.

Design/methodology/approach - Employees working in five-star hotels in Antalya province constitute the population of the research. The analysis was evaluated based on 583 people working in different departments of the hotels that responded to the survey, and the differences according to demographic variables were analysed using the parametric testing techniques t-Test and ANOVA analysis. In case of a difference in ANOVA test, Tukey test was used for double difference.

Findings - No statistically significant difference could be found in terms of demographic characteristics consisting of gender, marital status, educational background, monthly income, total income of the family, whether their nationality is Turkish or foreign, whether childhood was spent in a different place, choice of profession and the dimensions of emotional intelligence. However, differences were detected with respect to emotional intelligence and the status of the employee, their duration of service in the enterprise, and the departments in which they work.

Discussion - In this study conducted on hotel employees, it was observed that emotional intelligence scores increased in line with higher employee status. Although the result of this research cannot be generalised, it is considered it will contribute to the field. 


\section{Giriş}

Duygu tanımı alanyazıda çeşitlilik göstermekte ve tek bir tanımı yapılmamaktadır. Duygular, kişiyi harekete geçiren enerjiyi temin etmek ve gereksinimlerini karşılamak için uygun davranışa yönlendirici olmak üzere iki amacı vardır. Duygular olumlu, olumsuz olarak meydana gelir, "pozitif ve negatif olarak ifade edilir. Pozitif duygular heyecan, mutluluk, neşe, iyimserlik gibi tanımlanırken, negatif duygular ise, korku, kızgınlık, kin, düşmanlık, öfke, şiddet, kıskançlık, keder, üzüntü, tükenmişlik vb". olarak tanımlanmaktadır (Eröz,2011:10-11). Türk Dil Kurumu göre duygu; "Duyularla algılama, his", "Belirli nesne, olay veya bireylerin insanın iç dünyasında uyandırdığı izlenim", "Nesneleri veya olayları ahlaki ve estetik yönden değerlendirme yeteneği", "Önsezi", "Kendine özgü bir ruhsal hareket ve hareketlilik" olarak tanımlanmaktadır( http://tdk.gov.tr). Yelkikalan'ın aktarımına göre duygu; "bireyin doğaya ve topluma uyum sağlamasıdır" (Yelkikalan,2006:42).

Duygusal zeka kavramını açıklamadan önce zeka tanımını yapmak gerekirse; Gürel ve Tat 'ın zeka tanımı ile ilgili aktarımına göre zeka; "dünyayı algılama, algıları belleğe yerleştirme ve bu içerik üzerinde düşünme süreci"; "bireyin rasyonel düşünme, amaçlı davranma ve çevresiyle etkili biçimde baş edebilme becerilerinin tümü", "çevreye ve yeni durumlara uygun biçimde düşünüp davranarak uyum sağlama yeteneğini' dir (Gürel ve Tat,2010:339). Thorndike zekayı, soyut, mekanik ve sosyal zeka olarak üç bölüme ayırmıştır. Sosyal zeka "sosyal durumlara uyum ve sosyal bilginin kullanımı" olarak ifade edilmektedir(Doğan ve Şahin:234) Howard Gardner iki boyutlu olan zekayı farklı boyutlar katarak Çoklu Zeka Kuramı ile yedi tür zekanın varlığını belirtmiştir (Gökhan, 2011:7). Bugün uzmanların üzerinde anlaştığı zeka türleri; sözel, görsel, mantıksal, fiziksel, yaratıcı, duygusal zeka olmak üzere altı farklı şekilde kategorize edilmektedir (Yelkikalan,2006:41-42).

Duygusal Zeka (EI) terimi ilk olarak 1990 yılında bilimsel literatüre girmiş ve çeşitli teorisyenler tarafından tanımlanmıştır(Eröz,2013:214). Daniel Goleman duygusal zeka kavramını kullanmış ve bilişsel zekadan (QI) daha önemli olduğunun fikrini ileri sürmüştür (Gökhan, 2011:7). Psikoloji ve sosyoloji alanında daha fazla üzerine durulan ve çalışılan duygusal zekanın zaman içerisinde bireylerin yaşamını etkilediği kadar iş yaşamını da olumlu etkilediği konusunda düşünceler geliştirilmiş ve bu alana yönelik çalışmaları arttırmıştır. Örgütlerde bilişsel zeka (IQ) yanında, duygusal zekanın(EI) insan odaklı yaklaşımlarda önem kazandığı ve duygusal becerilerin gerekli olduğu fikri önem kazanmaktadır (Eröz,2013:214).

Duygusal zeka, diğer zeka türleri ile ilişkili olsa da diğerlerinden farklıdır. Kişinin yaşam süresi boyunca gelişir ve eğitim yoluyla arttırılabilir. Duygusal zeka bir kişinin duyguları (kendinin ve başkalarının) tanımlama ve algılama yeteneklerinin yanı sıra, bu duyguları yönetme becerilerini içerir(Scott vd.,2006:19). Bilim adamları ve araştırmacılar duygusal zekanın tanımını(Goleman 1998; Salovey ve Caruso 1997; Bar-On 1988; Cooper ve Sawaf'a 2003) farklı şekilde yapmış ve konuya farklı bakış açısıyla yaklaşmışlardır (Sevin ve Özil,2019:2039). Duygusal zeka, genel olarak, yetenek(Salovey ve Mayer) ve özellik(Bar-on) olmak üzere iki modelle açıklanmaktadır. Yetenek modeline göre; "Kendinin ve diğerlerinin his ve duygularını izleme; bunları ayırt edebilme ve bu bilgiyi kullanarak düşünce ve hareketlerini yönlendirebilme becerisi" olarak, özellik modeli ise; Bar-on'un öne sürdüğü "bireyin yaşantısındaki değişik durumların başarılı bir biçimde üstesinden gelmesini sağlayan, bilişsel olmayan tüm özellikler duygusal zekâ olarak" ifade edilmektedir (Şahin vd.,2009:244).

Salovery ve Mayer(1990), bireyin kendisi ve başkalarının duygularını izleme, duygular arası ayrım yapabilme ve bu bilgileri düşünce ve davranışları yönlendirmede kullanabilme yeteneği olarak, duygusal zekayı tanımlamışlardır. Bu tanımdan da anlaşılacağı üzere sosyal zekanın bir alt boyutu olan, duygusal zekanın boyutlar1;

- Duygularının farkına varma,

- Duygularla başa çıkma

- Kendini motive etme

- Başkalarının duygularını anlama ve

- İlişkileri yürütebilmek olarak beş başlıkla açıklanmaktadır(Sevin ve Özil, 2019:2040).

Duygusal zeka "işyerinde başarı için önemli bir faktör olarak kabul" edilmektedir(Yelkikalan,2006:46). Konakay'ın aktarımına göre California Üniversitesi'nde yapılan bir araştırmaya göre duygusal zekası yüksek 
olan bireylerin, "sosyal açıdan dengeli; dışa dönük, güvenli kişiler olduğu" görülmüştür(Konakay,2013:123). Örgüt çalışanlarının istenilen amaçlara ulaşabilmesi ve başarının sağlanmasında bilişsel zekanın tek başına yeterli olamayacağı, çalışanların duygusal zekaya da sahip olmaları gerektiği ve duygusal zeka düzeyi yüksek olanların düşük olanlara göre daha başarılı olduğu görüşü yaygındır. Örgütleri başarılı kılan bir çok unsurun yanında her geçen gün değişen müşterilerin ihtiyaç, istek ve beklentilere uygun şekilde cevap verebilmek duygusal zekası yüksek, yönetici, lider ve çalışanlar ile mümkün olacaktır(Arslan vd.,2013:173). Bir başka ifadeyle gelişmiş duygusal zeka düzeyi, duyguların kolay kontrol edilebilmesi, başkalarının duygularını anlama, etkili iletişim kurabilme yeteneği sağlar, aynı zamanda bireylerin özel yaşamında sağlığını, iş yaşamında performansını olumlu etkiler.

Turizm sektörü; Ziyaretçilerin ve yerel halkın konaklama, tatil, iş, eğlence ihtiyaçlarını karşılamak için faaliyet gösteren, konaklama, hotel, motel, yiyecek içecek, eğlence, dinlenme vb. gibi hizmet işletmelerinden oluşur. Konaklama işletmelerinde emek yoğun, hizmet odaklı ve insan ilişkileri yüksektir. Konukların memnuniyeti ve çalışanların başarısı, yöneticilerin ilgili kişilerin mevcut durumu ve kişilerin ihtiyaçlarını doğru şekilde anlama, içselleştirme ve çözümlemesi ile mümkündür. Duygular takım ruhunu oluşturmada ve düşünceleri iletmede önemlidir(Scott vd,2006:6-7).

Bu çalışmada turizm işletmelerinden biri olan otel işletmelerinde çalışanların demografik özelliklerine göre duygusal zeka (EI) düzeylerinin incelenmesi amaçlanmıştır.

\section{Duygusal Zeka Üzerine Yapılan İlgili Çalışmalar}

Duygusal zeka ve çalışma yaşamına ilişkin alanyazıda bir çok çalışma yapılmış, duygusal zeka ile iş tatmini, örgütsel bağlılık, psikolojik yıldırma, başarı, mesleki tükenmişlik, örgütsel vatandaşlık, çatışma, performans, liderlik ve iletişim ilişkilendirilmiştir. Bu çalışmaların bazıları şöyledir;

Çelenk (2015), tarafından yapılan araştırmada, "duygusal zekâ ile psikolojik yıldırma düzeyleri arasında anlamlı bir farklılık bulunamamış, duygusal zekâ ortalamaları psikolojik yıldırma düzeyi arttıkça duygusal zekâ ortalamasının azaldığı tespit edilmiş, ayrıca araştırmada duygusal zekânın, cinsiyet, meslekteki kıdem süresi, unvan, medeni duruma göre bir farklılık göstermediği, birim açısından farklılık gösterdiğii" sonucuna ulaşılmıştır.

Genç ve Gümüş (2016) tarafından yapılan, “Otel İşletmelerinde Duygusal Zekanın İş Stresi ve İş Yaşam Dengesi Üzerindeki Etkisi" konulu çalışmada, otel işletmelerinde çalışanların duygusal zekalarının iş stresi üzerinde kısmen anlamlı etkiye sahip olduğu, bunun yanında iş yaşam dengesi üzerinde anlamlı bir etkiye sahip olmadı̆̆ı" tespit edilmiştir.

Gürbüz ve Yüksel(2008) tarafından yapılan, “Çalışma Ortamında Duygusal Zeka: İş Performansı, İş Tatmini, Örgütsel Vatandaşlık Davranışı ve Bazı Demografik Özelliklerle İlişkisi konulu çalışmada, duygusal zekanın iş performansı, iş tatmini, örgütsel vatandaşlık davranışı ile anlamlı bir ilişkisi tespit edilememiş, duygusal zekanın işgörenlerin yaş, cinsiyet ve eğitim durumlarına göre anlamlı farklılığı olduğu, kadın işgörenlerin duygusal zekaları erkek işgörenlere göre daha yüksek olduğu ve işgörenlerin eğitim düzeyi arttıkça genel olarak duygusal zekaları da arttığı" görülmüştür.

Ural(2001), “Yöneticilerde Duygusal Zekanın Üç Boyutu adlı çalışmasında, konaklama işletmeleri yöneticilerinin, duygusal zekanın üç boyutuna ilişkin yeterliği ileri düzeyde gerçekleşerek, pek çok durumda sürekli ve dengeli bir duygusal zeka düzeyine sahip oldukları, yönetsel başarıda duygusal zeka bileşenlerinin birbirinden bağımsız olamayacakları" sonucuna varılmıştır.

Robert ve Barsede'nin (2008) tarafından çalışmalarında duygusal zekanın, iş performansını, iş yerinde sosyal ilişkileri, akademik başarı, aile ile daha yakın ilişki kurulmasını olumlu etkilediği, duygusal zeka düzeyi yüksek olanların düşük olanlara göre empatik ve sosyal becerisinin daha yüksek olduğu belirtilmektedir.

Shahhosseini vd. (2013) çalışmalarında, duygusal zeka ve iş performansı arasında pozitif yönlü bir ilişki bulmuşlardır.

Güllüce ve İşcan (2010) Mesleki Tükenmişlik ve Duygusal Zeka Arasındaki İlişkiyi araştırmış ve mesleki tükenmişlik ile duygusal zeka arasında ters yönlü bir ilişki olduğunu tespit etmişlerdir. Konakay (2013) çalışmasında akademisyenlerin medeni durumu, çalışma alanı, görev yılı ile duygusal zekâ düzeylerinde ve tükenmişlik düzeylerinde bir farklılık tespit etmiştir. 
H. D. Sevin - A. Uygur - M. B. Koyuncu 12/3 (2020) 2611-2628

Polatcı ve Özyer (2015), “Duygusal Emek Stratejilerinin Duygusal Zekanın Tükenmişliğe Etkisindeki Aracıllk Rolü"nü araştırmış, duygusal emek stratejilerinden yüzeysel davranış ve samimi duygular duygusal zekanın tükenmişlik üzerindeki etkisinde kısmi aracılık rolü oynadığını, derinlemesine davranış stratejisinin aracılık rolü üstlenmediğini tespit etmiştir.

Turhan ve Çetinsöz(2019), “Duygusal Zekâ ve Motivasyon Arasındaki İlişki: Turizm Programı Öğrencileri Üzerine" yaptıkları çalışmada, duygusal zekânın genel motivasyonu, içsel ve dışsal motivasyonu pozitif yönde etkilediğini bulmuşlardır.

Yılmaz vd.(2014) duygusal zeka ve örgüt iklimi konusunda yaptıkları araştırma sonucunda kamu kurumlarında çalışan memurların duygusal zekâ eğiliminin yüksek olduğu tespit edilmiş ve bu bağlamda çalışanların örgüt ikliminde pozitif davranışlar sergileyerek, örgütün başarısının artmasını sağladıkları tespit edilmiştir.

Sevin ve Özdil(2019) “Öğretmenlerin Rekreasyon Aktivitelerine Katılım Düzeyleri İle Duygusal Zeka ve Yaşam Tatmini Arasında İlişki" belirlemeye yönelik yaptıkları çalışmada duygusal zekanın demografik özelliklerden cinsiyet ve yaş'a göre farkl1lık gösterdiğini tespit etmişlerdir.

Pelit ve Ayana(2016) “Otel işletmeleri işgörenlerinin duygusal zekâ düzeylerinin örgütsel sinizm davranışları üzerindeki etkisinin belirlenmesine yönelik yaptıkları araştırmada, işgörenlerin duygusal zekâ ile örgütsel sinizm düzeyleri arasında ters yönlü ilişkinin olduğunu ortaya koymuşlardır

\section{Yöntem}

\section{Araştırmanın Amacı}

$\mathrm{Bu}$ araştırmanın temel amacı, otel çalışanlarının demografik özelliklerine göre duygusal zeka düzeylerinin incelenmesidir. Araştırmanın alt amaçları demografik değişkenlere göre duygusal zeka düzeyinin farklılık gösterip, göstermediğini tespit ve değerlendirilmesidir.

\section{Araştırmanın Hipotezleri}

Araştırmanın temel hipotezi şu şekilde oluşturulmuştur.

H1: Otel çalışanlarının demografik özelliklerine göre duygusal zeka düzeyleri farklılık göstermektedir.

Araştırmanın alt hipotezleri de şunlardır:

H1.1. Çalışanların duygusal zeka düzeyi cinsiyete göre farklılık gösterir.

H1.2: Çalışanların duygusal zeka düzeyi yaşa göre göre farklılık gösterir.

H1.3: Çalışanların duygusal zeka düzeyi medeni duruma göre farklılık gösterir.

H1.4: Çalışanların duygusal zeka düzeyi öğrenim durumu göre farklılık gösterir.

H1.5: Çalışanların duygusal zeka düzeyi aylık gelir göre farklılık gösterir.

H1.6: Çalışanların duygusal zeka düzeyi ailenin toplam gelirine göre farklılık gösterir.

H1.7: Çalışanların duygusal zeka düzeyi işletmedeki statüsüne göre farklılık gösterir

H1.8: Çalışanların duygusal zeka düzeyi çalışılan bölüm/departmana göre farklılık gösterir.

H1.9: Çalışanların duygusal zeka düzeyi işletmede/işletme grubunda çalışma süresine göre farklılık gösterir.

H1.10: Çalışanların duygusal zeka düzeyi turizm sektöründe çalışma süresine göre farklılık gösterir.

H1.11.: Çalışanların duygusal zeka düzeyi uyruğuna göre farklılık gösterir.

H1.12.: Çalışanların duygusal zeka düzeyi çocukluğunu geçirdiği yere göre farklılık gösterir.

H1.13.: Çalışanların duygusal zeka düzeyi günde çalışma süresine göre farklılık gösterir.

H1.14.: Çalışanların duygusal zeka düzeyi mesleğin seçimine göre farklılık gösterir.

\section{Araştırmanın Evreni ve Örneklem}

$\mathrm{Bu}$ araştırmanın evreni Antalya ilinde bulunan 5 yıldızlı otel çalışanlarıdır. Evren bilinmediğinde örneklem hesaplaması yapılabilmektedir. $\mathrm{n}=\left(\mathrm{t} 2^{*} \mathrm{p}^{*} \mathrm{q}\right) / \mathrm{d} 2$ formülü ile sayı hesaplanmaktadır. $\% 95$ güven düzeyi ve $\% 5$ örneklem hatasında örneklem sayısı 384 olarak hesaplanmıştır. Çalışmanın kapsamında 583 kişi ankete katılmış ve yanıtlar değerlendirmeye alınmıştır. 


\section{Araştırmanın Veri Toplama Araçları}

Araştırmada veri toplama aracı olarak, "Kişisel Bilgi Formu " ve "Duygusal Zeka Ölçeği" kullanılmıştır. Kişisel Bilgi Formu; Otel işletmelerinde çalışanların duygusal zeka düzeyini etkileyeceği düşünülen cinsiyet, yaş, medeni durum, öğrenim durum, aylık gelir, ailenin toplam geliri, işletmedeki statü, çalışılan bölüm/departman, işletmede/işletme grubunda çalışma süresi, turizm sektöründe çalışma süresi, uyruğu, çocukluğun geçirdiği yer, günlük çalışma süresi, mesleğin seçimi gibi kişisel bilgiler sorgulanmıştır. Duygusal Zeka Ölçeği; Göçet tarafından Türkçe'ye uyarlayan "Duygusal Zeka Ölçeği” kullanılmıştır. Bu çalışmada anketin uygulama tarihi 2019 yılı ve Ağustos ayı içindedir.

\section{Araştırmada Veri Analizi}

Verilerin analizi SPSS programı ile yapılmış ve \%95 güven düzeyi ile çalışılmıştır. Duygusal Zeka boyut puanlarının çarpıklık ve basıklık değerleri -3 ile +3 arasında olduğundan normal dağılıma uygun olduğu belirlenmiştir. Duygusal Zeka boyut puanlarının demografik değişkenlere göre farklılık gösterme durumu parametrik olan test tekniklerinden $\mathrm{t}$ ve ANOVA testleri ile analiz edilmiştir. ANOVA testinde fark çıkması durumunda ikili fark için Tukey testi kullanılmıştır.

\section{Geçerlilik ve Güvenirlilik Analizi}

Bu araştırmada, Schutte ve diğerleri (1998) tarafından geliştirilen, Austin ve diğerleri (2003) tarafından modifiye edilen ve Göçet tarafından Türkçe'ye uyarlayan "Duygusal Zeka Ölçeği" kullanılmıştır. Göçet tarafından yapılan çalışmada, "ilk faktör analizinde, döngüsüz metod (unrotated) kullanılarak faktör çözümlemesiyle maksimum faktör sayısı incelenmiş ve envanterin tek faktörlü olduğu belirlenmiştir. Bu incelemeden sonra tekrar yapılan faktör analizinde temel bileşenler tekniği ile oblique rotasyon faktör çözümlemesi sonuçları 3 faktörlülükle sinırlandırılmıştır. Bu işlem sonucunda toplam varyansın yaklaşık \% 60'ini açıklayan 3 faktörlü bir yapı ortaya çıkmıştır. Açıkladıkları varyans sırasına göre tüm faktör yapıları incelenmiş ve yapı geçerliği bulguları olarak değerlendirilmiştir. Birinci faktör olarak bulunan yapı "İyimserlik" adı altında ele alınmıştır. Bu faktör altındaki maddelerin faktör yükleri .37 ile .63 arasında değişmektedir. Bu faktör toplam varyansın \% 14'ünü açıklamakta ve 17 maddeden oluşmaktadır. İkinci faktör olarak bulunan "Duygulardan faydalanma" 6 maddeden oluşmaktadır. Bu boyuta ait maddelerin faktör yükleri .30 ile .57 arasında değişmektedir. Bu faktör toplam varyansın \%20.4'ünü açılamaktadır. Üçüncü faktör olarak bulunan yapı "Duyguların ifadesi" adı altında ele alınmıştır. Bu faktör altındaki maddelerin faktör yükleri .32 ile .61 arasında değişmektedir. Bu faktör toplam varyansın \%25.9'unu açıklamakta ve 14 maddeden oluşmaktadır. Ölçeğin Cronbach alfa iç tutarlık kat sayıları ölçeğin bütünü için .81, iyimserlik faktörü için .77, duyguların ifadesi için .73 ve duygulardan faydalanma faktörü için .54 olarak bulunmuştur. İki yarı güvenirliğinde ise İyimserlik .71, Duyguların İfadesi .72 ve Duygulardan Faydalanma .52 olarak bulunmuştur. Ölçeğin bütünü için ise .78 olarak" bulunmuştur(Göçet,2006:53-60). Bu durumda ölçek yüksek derecede güvenilir kabul edildiğinden bu araştırmada kullanılmış ve tekrar faktör analizi yapılmamıştır.

\section{Bulgular}

Bu bölümde, araştırmaya katılan otel çalışanlarının demografik özellikleri göre, duygusal zeka düzeylerine yönelik bulgular yer almaktadır.

Tablo 1. Ankete Katılanların Demografik Özellikleri

\begin{tabular}{llcc}
\hline & & $\mathrm{n}$ & $\%$ \\
\hline \multirow{2}{*}{ Cinsiyet } & Kadın & 261 & 44,8 \\
& Erkek & 322 & 55,2 \\
\hline \multirow{3}{*}{ Yaş } & 17 ve Altı & 48 & 8,2 \\
& $18-24$ & 161 & 27,6 \\
& $25-34$ & 189 & 32,4 \\
& $35-44$ & 151 & 25,9 \\
& $45-54$ & 29 & 5,0 \\
& 55 ve Üzeri & 5 &, 9 \\
\hline
\end{tabular}


H. D. Sevin - A. Uygur - M. B. Koyuncu 12/3 (2020) 2611-2628

\begin{tabular}{|c|c|c|c|}
\hline \multirow{2}{*}{ Medeni Durum } & Evli & 228 & 39,1 \\
\hline & Bekar & 355 & 60,9 \\
\hline \multirow{6}{*}{ Öğrenim Durumu } & İlköğretim & 61 & 10,5 \\
\hline & Ortaöğretim & 223 & 38,3 \\
\hline & Ön Lisans & 177 & 30,4 \\
\hline & Lisans & 94 & 16,1 \\
\hline & Yüksek Lisans & 26 & 4,5 \\
\hline & Doktora & 2 & ,3 \\
\hline \multirow{12}{*}{ Aylık Gelir } & $1.500-2.500 \mathrm{TL}$ & 180 & 30,9 \\
\hline & $2.501-3.000 \mathrm{TL}$ & 222 & 38,1 \\
\hline & $3.001-3.500 \mathrm{TL}$ & 64 & 11,0 \\
\hline & $3.501-4.000 \mathrm{TL}$ & 28 & 4,8 \\
\hline & $4.001-4.500 \mathrm{TL}$ & 14 & 2,4 \\
\hline & $4.501-5.000 \mathrm{TL}$ & 13 & 2,2 \\
\hline & $5.001-5.500 \mathrm{TL}$ & 21 & 3,6 \\
\hline & $5.501-6.000 \mathrm{TL}$ & 7 & 1,2 \\
\hline & $6.001-6.500 \mathrm{TL}$ & 3 &, 5 \\
\hline & $6.501-7.000 \mathrm{TL}$ & 10 & 1,7 \\
\hline & 7.001-7.500 TL & 6 & 1,0 \\
\hline & 7.5001 TL ve Üzeri & 15 & 2,6 \\
\hline \multirow{16}{*}{ Ailenin Toplam Geliri } & $1.500-2.500 \mathrm{TL}$ & 59 & 10,1 \\
\hline & $2.501-3.000 \mathrm{TL}$ & 107 & 18,4 \\
\hline & $3.001-3.500 \mathrm{TL}$ & 68 & 11,7 \\
\hline & $3.501-4.000 \mathrm{TL}$ & 42 & 7,2 \\
\hline & 4.001-4.500 TL & 45 & 7,7 \\
\hline & $4.501-5.000 \mathrm{TL}$ & 50 & 8,6 \\
\hline & $5.001-5.500 \mathrm{TL}$ & 46 & 7,9 \\
\hline & $5.501-6.000 \mathrm{TL}$ & 23 & 3,9 \\
\hline & $6.001-6.500 \mathrm{TL}$ & 18 & 3,1 \\
\hline & $6.501-7.000 \mathrm{TL}$ & 34 & 5,8 \\
\hline & 7.001-7.500 TL & 23 & 3,9 \\
\hline & 7.500-8.000 TL & 9 & 1,5 \\
\hline & $8.001-8.500 \mathrm{TL}$ & 9 & 1,5 \\
\hline & $8.501-9.000 \mathrm{TL}$ & 9 & 1,5 \\
\hline & 9.001-9.500 TL & 14 & 2,4 \\
\hline & 9.501 TL ve Üzeri & 27 & 4,6 \\
\hline \multirow{5}{*}{ İşletmedeki Statü } & Stajyer & 68 & 11,7 \\
\hline & Departman Çalışanı & 375 & 64,3 \\
\hline & $\begin{array}{l}\text { Departman Müdür Yrd/Asistanı-Kısım Şefi- } \\
\text { Şef }\end{array}$ & 110 & 18,9 \\
\hline & Departman Müdürü & 24 & 4,1 \\
\hline & Genel Müdür/Otel Müdürü & 6 & 1,0 \\
\hline
\end{tabular}


H. D. Sevin - A. Uygur - M. B. Koyuncu 12/3 (2020) 2611-2628

\begin{tabular}{|c|c|c|c|}
\hline & Servis & 116 & 19,9 \\
\hline & Mutfak & 134 & 23,0 \\
\hline & Ön Büro & 59 & 10,1 \\
\hline & Kat Hizmetleri & 116 & 19,9 \\
\hline & Animasyon & 22 & 3,8 \\
\hline & Misafir İlişkileri & 30 & 5,1 \\
\hline & Muhasebe & 26 & 4,5 \\
\hline Çalış1lan Bölüm/Departman & İnsan Kaynakları & 18 & 3,1 \\
\hline & Satın Alma & 6 & 1,0 \\
\hline & Sağllk Klübü\&SPA & 9 & 1,5 \\
\hline & Teknik Servis & 6 & 1,0 \\
\hline & Güvenlik & 17 & 2,9 \\
\hline & Cankurtaran & 8 & 1,4 \\
\hline & Genel Müdürlük/Yönetim & 10 & 1,7 \\
\hline & Diğer İse Belirtiniz & 6 & 1,0 \\
\hline & 1 Yil ve Daha Az & 183 & 31,4 \\
\hline & 2-4 Yil & 254 & 43,6 \\
\hline İşletmede/İşletme Grubunda Çalışma Süresi & 5-7 Yil & 106 & 18,2 \\
\hline & 8-10 Yil & 21 & 3,6 \\
\hline & 11 Yil ve Üzeri & 19 & 3,3 \\
\hline & 1 Yll ve Daha Az & 103 & 17,7 \\
\hline & 2-4 Y1l & 213 & 36,5 \\
\hline Turizm Sektöründe Çalışma Süresi & 5-7 Y1l & 150 & 25,7 \\
\hline & 8-10 Yil & 65 & 11,1 \\
\hline & 11 Y1l ve Üzeri & 52 & 8,9 \\
\hline 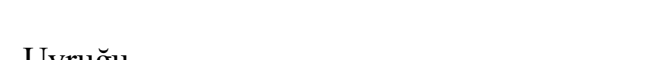 & Türkiye Cumhuriyeti & 523 & 89,7 \\
\hline Oyrugu & Yabancı Uyruklu & 60 & 10,3 \\
\hline & Köy-Belde & 135 & 23,2 \\
\hline Çocukluğun Geçirdiği Yer & İlçe & 217 & 37,2 \\
\hline & İl & 231 & 39,6 \\
\hline & 8 Saatten $\mathrm{Az}$ & 35 & 6,0 \\
\hline Günde Çalışma Süresi & 8 Saat & 417 & 71,5 \\
\hline & 8 Saaten Fazla & 131 & 22,5 \\
\hline Mecleăi isteyerel mi Sectin & Evet & 425 & 72,9 \\
\hline Meslegi isteyerek mi seçtiniz & Hayır & 158 & 27,1 \\
\hline
\end{tabular}

Ankete cevap veren katılımcılardan; Erkeklerin oranı \%55,2; 25-34 yaş arası olanların oranı \%32,4; bekar olanların oranı \%60,9; ortaöğretim mezunu olanların oranı \%38,3; aylık geliri 2501-3000 TL arası olanların oranı \%38,1; ailesinin toplam geliri 2501-3000 TL arası olanların oranı $\% 18,4$ 'tür. İşletmedeki statüsü departman çalışanı olanların oranı \%64,3; mutfakta çalışanların oranı $\% 23,0$; bu işletmede 2-4 yıldır çalışanların oranı \%43,6; turizm sektöründe 2-4 yıldır çalışanların oranı \%36,5; Türk olanların oranı \%89,7; çocukluğu ilde geçmiş olanların oranı \%39,6; günde 8 saat çalışanların oranı $\% 71,5$; mesleğini isteyerek seçmiş olanların oranı $\% 72,9^{\prime}$ dur. 
H. D. Sevin - A. Uygur - M. B. Koyuncu 12/3 (2020) 2611-2628

Tablo 2. Duygusal Zeka Puanlara Ait Betimsel İstatistikler

\begin{tabular}{lccccccc}
\hline & $\mathrm{n}$ & Minimum & Maximum & Ortalama & ss & Çarpıklık & Basıklık \\
\hline İyimserlik & 583 & 1,24 & 5,00 & 3,45 & 0,78 &,- 548 &, 225 \\
\hline Duygulardan Faydalanma & 583 & 1,00 & 5,00 & 2,76 & 0,88 &, 281 &,- 056 \\
\hline Duyguların İfadesi & 583 & 1,57 & 5,00 & 2,97 & 0,68 &, 634 &,- 018 \\
\hline Duygusal Zeka & 583 & 2,16 & 4,68 & 3,16 & 0,39 & 1,560 & 2,362 \\
\hline
\end{tabular}

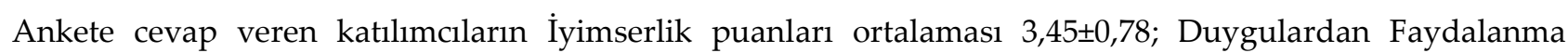

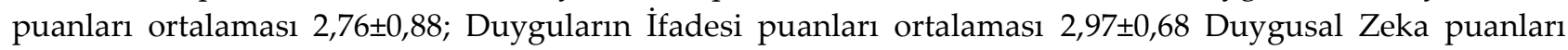
ortalaması 3,16 $\pm 0,39$ 'dur. Duygusal Zeka puanlarından elde edilen çarpıklık ve basıklık katsayıları +3 ile -3 arasında olduğundan normallik sağlanmış ve analizlerde parametrik olan test teknikleri kullanılmıştır.

Tablo 3. Duygusal Zekanın Cinsiyet Açısından İncelenmesi

\begin{tabular}{|c|c|c|c|c|c|c|}
\hline Cinsiyet & & $\mathrm{n}$ & Ortalama & ss & $\mathrm{t}$ & $\mathrm{p}$ \\
\hline \multirow{2}{*}{ İyimserlik } & Kadın & 261 & 3,49 & 0,80 & \multirow{2}{*}{1,100} & \multirow{2}{*}{,272 } \\
\hline & Erkek & 322 & 3,42 & 0,77 & & \\
\hline \multirow{2}{*}{ Duygulardan Faydalanma } & Kadın & 261 & 2,74 & 0,90 & \multirow{2}{*}{$-0,628$} & \multirow{2}{*}{, 530} \\
\hline & Erkek & 322 & 2,78 & 0,87 & & \\
\hline \multirow{2}{*}{ Duyguların İfadesi } & Kadın & 261 & 2,99 & 0,69 & \multirow{2}{*}{0,670} & \multirow{2}{*}{,503 } \\
\hline & Erkek & 322 & 2,96 & 0,67 & & \\
\hline \multirow{2}{*}{ Duygusal Zeka } & Kadın & 261 & 3,18 & 0,39 & \multirow{2}{*}{1,225} & \multirow{2}{*}{,221 } \\
\hline & Erkek & 322 & 3,14 & 0,39 & & \\
\hline
\end{tabular}

${ }^{*} \mathrm{p}<0,05$

Duygusal Zekanın Cinsiyet Açısından İncelenmesi için yapılan $\mathrm{t}$ testi sonuçlarına göre; Kadın ile erkekler arasında Duygusal Zeka boyutları açısından istatistiksel olarak anlamlı farklılık bulunmamaktadır $(\mathrm{p}>0,05)$.

Tablo 4. Duygusal Zekanın Yaş Açısından İncelenmesi

\begin{tabular}{|c|c|c|c|c|c|c|c|}
\hline Yaş & & $\mathrm{n}$ & Ortalama & ss & $\mathrm{F}$ & $\mathrm{p}$ & Çoklu Karşılaştırma \\
\hline \multirow{5}{*}{ İyimserlik } & 17 ve Altı & 48 & 3,35 & 0,97 & \multirow{5}{*}{, 569} & \multirow{5}{*}{ 685 } & \\
\hline & $18-24$ & 161 & 3,51 & 0,67 & & & \\
\hline & $25-34$ & 189 & 3,41 & 0,79 & & & \\
\hline & $35-44$ & 151 & 3,47 & 0,81 & & & \\
\hline & 45 ve üzeri & 34 & 3,40 & 0,85 & & & \\
\hline \multirow{5}{*}{ Duygulardan Faydalanma } & 17 ve Altı & 48 & 2,95 & 0,91 & \multirow{5}{*}{1,830} & \multirow{5}{*}{,121 } & \\
\hline & $18-24$ & 161 & 2,70 & 0,82 & & & \\
\hline & $25-34$ & 189 & 2,67 & 0,89 & & & \\
\hline & $35-44$ & 151 & 2,86 & 0,91 & & & \\
\hline & 45 ve üzeri & 34 & 2,86 & 0,89 & & & \\
\hline \multirow{5}{*}{ Duyguların İfadesi } & 17 ve Altı & 48 & 3,13 & 0,71 & \multirow{5}{*}{2,927} & \multirow{5}{*}{, $020^{*}$} & \multirow{5}{*}{$2<4$} \\
\hline & $18-24$ & 161 & 2,86 & 0,59 & & & \\
\hline & $25-34$ & 189 & 2,93 & 0,69 & & & \\
\hline & $35-44$ & 151 & 3,07 & 0,73 & & & \\
\hline & 45 ve üzeri & 34 & 3,09 & 0,65 & & & \\
\hline \multirow{5}{*}{ Duygusal Zeka } & 17 ve Altı & 48 & 3,20 & 0,43 & \multirow{5}{*}{2,004} & \multirow{5}{*}{,092 } & \\
\hline & $18-24$ & 161 & 3,13 & 0,36 & & & \\
\hline & $25-34$ & 189 & 3,11 & 0,37 & & & \\
\hline & $35-44$ & 151 & 3,22 & 0,42 & & & \\
\hline & 45 ve üzeri & 34 & 3,20 & 0,38 & & & \\
\hline
\end{tabular}

${ }^{*} \mathrm{p}<0,05$ 
H. D. Sevin - A. Uygur - M. B. Koyuncu 12/3 (2020) 2611-2628

Duygusal Zekanın Yaş Açısından İncelenmesi için yapılan ANOVA testi sonuçları göre; Yaşı faklı olan gruplar arasında Duyguların İfadesi açısından istatistiksel olarak anlamlı farklılık bulunmaktadır ( $\mathrm{p}<0,05)$. 17 yaş ve altı olanların ortalaması 3,13; 18-24 yaş arası olanların ortalaması 2,86; 35-34 yaş arası olanların ortalaması 2,93; $35-44$ yaş arası olanların ortalaması 3,07; 45 yaş ve üzeri olanların ortalaması 3,09'dur. Buna göre 17 yaş ve altı olanların Duyguların İfadesi puan ortalaması en büyük iken 18-24 yaş arası olanların ortalaması en küçüktür.

Tablo 5. Duygusal Zekanın Medeni Durum Açısından İncelenmesi

\begin{tabular}{lllcccc}
\hline Medeni Durum & & $\mathrm{n}$ & Ortalama & $\mathrm{ss}$ & $\mathrm{t}$ & $\mathrm{p}$ \\
\hline \multirow{2}{*}{ İyimserlik } & Evli & 228 & 3,38 & 0,85 & \multirow{2}{*}{$-1,766$} & \multirow{2}{*}{, 078} \\
\hline \multirow{2}{*}{ Duygulardan Faydalanma } & Bekar & 355 & 3,49 & 0,73 & & \\
\hline \multirow{2}{*}{ Duyguların İfadesi } & Evli & 228 & 2,85 & 0,95 & \multirow{2}{*}{, 853} & \multirow{2}{*}{064} \\
& Bekar & 355 & 2,71 & 0,83 & & \\
\hline \multirow{2}{*}{ Duygusal Zeka } & Evli & 228 & 3,04 & 0,71 & \multirow{2}{*}{, 070} \\
& Bekar & 355 & 2,93 & 0,65 & & \\
& Evli & 228 & 3,16 & 0,38 & \multirow{2}{*}{, 250} & \multirow{2}{*}{, 803} \\
\hline
\end{tabular}

${ }^{*} \mathrm{p}<0,05$

Duygusal Zekanın Medeni Durum Açısından İncelenmesi için yapılan $t$ testi sonuçlarına göre; Evli ile bekar olanlar arasında Duygusal Zeka boyutları açısından istatistiksel olarak anlamlı farklılık bulunmamaktadır $(\mathrm{p}>0,05)$.

Tablo 6. Duygusal Zekanın Öğrenim Durumu Açısından İncelenmesi

\begin{tabular}{|c|c|c|c|c|c|c|}
\hline Öğgrenim durumu & & $\mathrm{n}$ & Ortalama & ss & $\mathrm{F}$ & $\mathrm{p}$ \\
\hline \multirow{5}{*}{ İyimserlik } & İlköğretim & 61 & 3,51 & 0,74 & \multirow{5}{*}{1,967} & \multirow{5}{*}{,098 } \\
\hline & Ortaöğretim & 223 & 3,45 & 0,73 & & \\
\hline & Ön Lisans & 177 & 3,42 & 0,82 & & \\
\hline & Lisans & 94 & 3,56 & 0,75 & & \\
\hline & Yüksek Lisans/Doktora & 28 & 3,11 & 1,02 & & \\
\hline \multirow{5}{*}{ Duygulardan Faydalanma } & İlköğretim & 61 & 2,55 & 0,83 & \multirow{5}{*}{1,567} & \multirow{5}{*}{,182 } \\
\hline & Ortaöğretim & 223 & 2,78 & 0,82 & & \\
\hline & Ön Lisans & 177 & 2,78 & 0,94 & & \\
\hline & Lisans & 94 & 2,75 & 0,87 & & \\
\hline & Yüksek Lisans/Doktora & 28 & 3,03 & 1,03 & & \\
\hline \multirow{5}{*}{ Duyguların İfadesi } & İlköğretim & 61 & 2,86 & 0,67 & \multirow{5}{*}{0,850} & \multirow{5}{*}{494} \\
\hline & Ortaöğretim & 223 & 2,95 & 0,63 & & \\
\hline & Ön Lisans & 177 & 2,98 & 0,74 & & \\
\hline & Lisans & 94 & 3,04 & 0,65 & & \\
\hline & Yüksek Lisans/Doktora & 28 & 3,07 & 0,71 & & \\
\hline \multirow{5}{*}{ Duygusal Zeka } & İlköğretim & 61 & 3,11 & 0,30 & \multirow{5}{*}{1,356} & \multirow{5}{*}{248} \\
\hline & Ortaöğretim & 223 & 3,15 & 0,39 & & \\
\hline & Ön Lisans & 177 & 3,15 & 0,41 & & \\
\hline & Lisans & 94 & 3,23 & 0,42 & & \\
\hline & Yüksek Lisans/Doktora & 28 & 3,08 & 0,36 & & \\
\hline
\end{tabular}

${ }^{*} \mathrm{p}<0,05$ 
H. D. Sevin - A. Uygur - M. B. Koyuncu 12/3 (2020) 2611-2628

Duygusal Zekanın Öğrenim Durumu Açısından İncelenmesi için yapılan ANOVA testi sonuçlarına göre; Öğrenim durumu farklı olan gruplar arasında Duygusal Zeka boyutları açısından istatistiksel olarak anlamlı farklılık bulunmamaktadır ( $\mathrm{p}>0,05)$.

Tablo 7. Duygusal Zekanın Aylık Gelir Açısından İncelenmesi

\begin{tabular}{|c|c|c|c|c|c|c|}
\hline Aylık gelir & & $\mathrm{n}$ & Ortalama & ss & $\mathrm{F}$ & $\mathrm{p}$ \\
\hline \multirow{5}{*}{ İyimserlik } & $1.500-2.500 \mathrm{TL}$ & 180 & 3,50 & 0,84 & \multirow{5}{*}{, 702} & \multirow{5}{*}{, 591} \\
\hline & $2.501-3.000 \mathrm{TL}$ & 222 & 3,44 & 0,73 & & \\
\hline & $3.001-3.500 \mathrm{TL}$ & 64 & 3,31 & 0,64 & & \\
\hline & $3.501-5.000 \mathrm{TL}$ & 55 & 3,47 & 0,74 & & \\
\hline & $5.001 \mathrm{TL}$ ve üstü & 62 & 3,46 & 0,94 & & \\
\hline \multirow{5}{*}{ Duygulardan Faydalanma } & $1.500-2.500 \mathrm{TL}$ & 180 & 2,75 & 0,94 & \multirow{5}{*}{, 334} & \multirow{5}{*}{855} \\
\hline & $2.501-3.000 \mathrm{TL}$ & 222 & 2,73 & 0,85 & & \\
\hline & $3.001-3.500 \mathrm{TL}$ & 64 & 2,77 & 0,70 & & \\
\hline & 3.501-5.000 TL & 55 & 2,82 & 0,83 & & \\
\hline & $5.001 \mathrm{TL}$ ve üstü & 62 & 2,86 & 1,03 & & \\
\hline \multirow{5}{*}{ Duyguların İfadesi } & $1.500-2.500 \mathrm{TL}$ & 180 & 2,99 & 0,71 & \multirow{5}{*}{1,043} & \multirow{5}{*}{,384 } \\
\hline & $2.501-3.000 \mathrm{TL}$ & 222 & 2,96 & 0,64 & & \\
\hline & 3.001-3.500 TL & 64 & 2,84 & 0,53 & & \\
\hline & $3.501-5.000 \mathrm{TL}$ & 55 & 3,06 & 0,80 & & \\
\hline & 5.001 TL ve üstü & 62 & 3,03 & 0,72 & & \\
\hline \multirow{5}{*}{ Duygusal Zeka } & $1.500-2.500 \mathrm{TL}$ & 180 & 3,18 & 0,42 & \multirow{5}{*}{2,091} & \multirow{5}{*}{081} \\
\hline & $2.501-3.000 \mathrm{TL}$ & 222 & 3,14 & 0,36 & & \\
\hline & $3.001-3.500 \mathrm{TL}$ & 64 & 3,04 & 0,28 & & \\
\hline & $3.501-5.000 \mathrm{TL}$ & 55 & 3,21 & 0,44 & & \\
\hline & 5.001 TL ve üstü & 62 & 3,20 & 0,41 & & \\
\hline
\end{tabular}

${ }^{*} \mathrm{p}<0,05$

Duygusal Zekanın Aylık Gelir Açısından İncelenmesi için yapılan ANOVA testi sonuçlarına göre; Aylık geliri farklı olan gruplar arasında Duygusal Zeka boyutları açısından istatistiksel olarak anlamlı farklılık bulunmamaktadır $(\mathrm{p}>0,05)$.

Tablo 8. Duygusal Zekanın Ailenin Toplam Geliri Açısından İncelenmesi

\begin{tabular}{|c|c|c|c|c|c|c|}
\hline Ailenizin toplam geliri & & $\mathrm{n}$ & Ortalama & ss & $\mathrm{F}$ & $\mathrm{p}$ \\
\hline \multirow{6}{*}{ İyimserlik } & $1.500-2.500 \mathrm{TL}$ & 59 & 3,38 & 0,88 & \multirow{6}{*}{1,193} & \multirow{6}{*}{311} \\
\hline & $2.501-3.000 \mathrm{TL}$ & 107 & 3,48 & 0,68 & & \\
\hline & $3.001-3.500 \mathrm{TL}$ & 68 & 3,49 & 0,77 & & \\
\hline & 3.501-5.000 TL & 137 & 3,34 & 0,81 & & \\
\hline & $5.001-7.000 \mathrm{TL}$ & 121 & 3,45 & 0,76 & & \\
\hline & 7.001 TL ve üzeri & 91 & 3,58 & 0,80 & & \\
\hline \multirow{6}{*}{ Duygulardan Faydalanma } & $1.500-2.500 \mathrm{TL}$ & 59 & 2,73 & 1,06 & \multirow{6}{*}{1,424} & \multirow{6}{*}{214} \\
\hline & $2.501-3.000 \mathrm{TL}$ & 107 & 2,68 & 0,78 & & \\
\hline & $3.001-3.500 \mathrm{TL}$ & 68 & 2,63 & 0,84 & & \\
\hline & 3.501-5.000 TL & 137 & 2,92 & 0,93 & & \\
\hline & 5.001-7.000 TL & 121 & 2,78 & 0,85 & & \\
\hline & 7.001 TL ve üzeri & 91 & 2,72 & 0,86 & & \\
\hline
\end{tabular}


H. D. Sevin - A. Uygur - M. B. Koyuncu 12/3 (2020) 2611-2628

\begin{tabular}{llccccc} 
& $1.500-2.500 \mathrm{TL}$ & 59 & 2,90 & 0,69 & & \\
& $2.501-3.000 \mathrm{TL}$ & 107 & 2,89 & 0,57 & & \\
Duyguların İfadesi & $3.001-3.500 \mathrm{TL}$ & 68 & 2,88 & 0,70 & 1,464 &, 200 \\
& $3.501-5.000 \mathrm{TL}$ & 137 & 3,08 & 0,69 & & \\
& $5.001-7.000 \mathrm{TL}$ & 121 & 2,97 & 0,69 & & \\
& $7.001 \mathrm{TL}$ ve üzeri & 91 & 3,01 & 0,72 & & \\
& $1.500-2.500 \mathrm{TL}$ & 59 & 3,10 & 0,42 & & \\
& $2.501-3.000 \mathrm{TL}$ & 107 & 3,13 & 0,32 & & \\
Duygusal Zeka & $3.001-3.500 \mathrm{TL}$ & 68 & 3,12 & 0,37 & & \\
& $3.501-5.000 \mathrm{TL}$ & 137 & 3,17 & 0,38 & & \\
& $5.001-7.000 \mathrm{TL}$ & 121 & 3,16 & 0,40 & & \\
& $7.001 \mathrm{TL}$ ve üzeri & 91 & 3,23 & 0,44 & & \\
\hline
\end{tabular}

${ }^{*} \mathrm{p}<0,05$

Duygusal Zekanın Ailenin Toplam Geliri Açısından İncelenmesi için yapılan ANOVA testi sonuçlarına göre; Ailesinin toplam geliri farklı olan gruplar arasında Duygusal Zeka boyutları açısından istatistiksel olarak anlamlı farklılık bulunmamaktadır ( $p>0,05)$.

Tablo 9. Duygusal Zekanın İşletmedeki Statü Açısından İncelenmesi

\begin{tabular}{|c|c|c|c|c|c|c|c|}
\hline İşletmedeki statünü & & $\mathrm{n}$ & Ortalama & ss & $\mathrm{F}$ & $\mathrm{p}$ & $\begin{array}{c}\text { Çoklu } \\
\text { karşılaştırma }\end{array}$ \\
\hline \multirow{4}{*}{ İyimserlik } & Stajyer & 68 & 3,44 & 0,92 & \multirow{4}{*}{,613 } & \multirow{4}{*}{607} & \\
\hline & Departman Çalışanı & 375 & 3,45 & 0,72 & & & \\
\hline & $\begin{array}{l}\text { Departman Müdür } \\
\text { Yrd/Asistanı-Kısım Şefi-Şef }\end{array}$ & 110 & 3,39 & 0,83 & & & \\
\hline & $\begin{array}{l}\text { Departman Müdürü/Genel } \\
\text { Müdür/Otel Müdürü }\end{array}$ & 30 & 3,60 & 0,94 & & & \\
\hline \multirow{4}{*}{$\begin{array}{l}\text { Duygulardan } \\
\text { Faydalanma }\end{array}$} & Stajyer & 68 & 2,81 & 1,03 & & & \multirow{4}{*}{$2<3$} \\
\hline & Departman Çalışanı & 375 & 2,69 & 0,83 & & & \\
\hline & $\begin{array}{l}\text { Departman Müdür } \\
\text { Yrd/Asistanı-Kısım Şefi-Şef }\end{array}$ & 110 & 2,98 & 0,89 & 3,262 &, $021^{*}$ & \\
\hline & $\begin{array}{l}\text { Departman Müdürü/Genel } \\
\text { Müdür/Otel Müdürü }\end{array}$ & 30 & 2,71 & 1,02 & & & \\
\hline \multirow{4}{*}{ Duyguların İfadesi } & Stajyer & 68 & 3,04 & 0,71 & & \multirow{4}{*}{, $001^{*}$} & \multirow{4}{*}{$2<3$} \\
\hline & Departman Çalışanı & 375 & 2,90 & 0,65 & & & \\
\hline & $\begin{array}{l}\text { Departman Müdür } \\
\text { Yrd/Asistanı-Kısım Şefi-Şef }\end{array}$ & 110 & 3,18 & 0,71 & 5,298 & & \\
\hline & $\begin{array}{l}\text { Departman Müdürü/Genel } \\
\text { Müdür/Otel Müdürü }\end{array}$ & 30 & 3,03 & 0,72 & & & \\
\hline \multirow{4}{*}{ Duygusal Zeka } & Stajyer & 68 & 3,19 & 0,43 & \multirow{4}{*}{3,584} & \multirow{4}{*}{, $014^{*}$} & \multirow{4}{*}{$2<3$} \\
\hline & Departman Çalışanı & 375 & 3,12 & 0,37 & & & \\
\hline & $\begin{array}{l}\text { Departman Müdür } \\
\text { Yrd/Asistanı-Kısım Şefi-Şef }\end{array}$ & 110 & 3,24 & 0,41 & & & \\
\hline & $\begin{array}{l}\text { Departman Müdürü/Genel } \\
\text { Müdür/Otel Müdürü }\end{array}$ & 30 & 3,24 & 0,44 & & & \\
\hline
\end{tabular}

${ }^{*} \mathrm{p}<0,05$ 
H. D. Sevin - A. Uygur - M. B. Koyuncu 12/3 (2020) 2611-2628

Duygusal Zekanın İşletmedeki Statü Açısından İncelenmesi için yapılan ANOVA testi sonuçlarına göre; İşletmedeki statüsü faklı olan gruplar arasında Duygulardan Faydalanma açısından istatistiksel olarak anlamlı farklılık bulunmaktadır $(\mathrm{p}<0,05)$. Stajyer olanların ortalaması 2,81; departman çalışanı olanların ortalaması 2,69; Departman Müdür Yrd/Asistanı-Kısım Şefi-Şef olanların ortalaması 2,98; Departman Müdürü/Genel Müdür/Otel Müdürü olanların ortalaması 2,71'dir. Buna göre Departman Müdür Yrd/Asistanı-Kısım Şefi-Şef olanların Duygulardan Faydalanma puan ortalaması en büyük iken Departman Çalışanı olanların ortalaması en küçüktür. İşletmedeki statüsü faklı olan gruplar arasında Duyguların İfadesi açısından istatistiksel olarak anlamlı farklılık bulunmaktadır $(p<0,05)$. Stajyer olanların ortalaması 3,04; departman çalışanı olanların ortalaması 2,90; Departman Müdür Yrd/Asistanı-Kısım Şefi-Şef olanların ortalaması 3,18; Departman Müdürü/Genel Müdür/Otel Müdürü olanların ortalaması 3,03'tür. Buna göre Departman Müdür Yrd/Asistanı-Kısım Şefi-Şef olanların Duyguların İfadesi puan ortalaması en büyük iken Departman Çalışanı olanların ortalaması en küçüktür. İşletmedeki statüsü faklı olan gruplar arasında Duygusal Zeka açısından istatistiksel olarak anlamlı farklılık bulunmaktadır $(\mathrm{p}<0,05)$. Stajyer olanların ortalaması 3,19; departman çalışanı olanların ortalaması 3,12; Departman Müdür Yrd/Asistanı-Kısım Şefi-Şef olanların ortalaması 3,24; Departman Müdürü/Genel Müdür/Otel Müdürü olanların ortalaması 3,24'tür. Buna göre Departman Müdür Yrd/Asistanı-Kısım Şefi-Şef ya da Departman Müdürü/Genel Müdür/Otel Müdürü olanların Duygusal Zeka puan ortalaması en büyük iken Departman Çalışanı olanların ortalaması en küçüktür.

Tablo 10. Duygusal Zekanın Çalışılan Bölüm/Departman Açısından İncelenmesi

\begin{tabular}{|c|c|c|c|c|c|c|c|}
\hline \multicolumn{2}{|c|}{ Çalıştığınız Bölüm/Departman } & \multirow{2}{*}{$\frac{\mathrm{n}}{116}$} & \multirow{2}{*}{$\begin{array}{c}\text { Ortalama } \\
3,42\end{array}$} & \multirow{2}{*}{$\frac{\text { ss }}{0,70}$} & \multirow[t]{2}{*}{$\mathrm{F}$} & \multirow[t]{2}{*}{$\mathrm{p}$} & \multirow[t]{2}{*}{$\begin{array}{c}\text { Çoklu } \\
\text { karşılaştırma }\end{array}$} \\
\hline \multirow{10}{*}{ İyimserlik } & Servis & & & & & & \\
\hline & Mutfak & 134 & 3,43 & 0,70 & \multirow{9}{*}{, 577} & \multirow{9}{*}{, 816} & \\
\hline & Ön Büro & 59 & 3,57 & 0,79 & & & \\
\hline & Kat Hizmetleri & 116 & 3,42 & 0,90 & & & \\
\hline & Animasyon & 22 & 3,29 & 0,86 & & & \\
\hline & Misafir İlişkileri & 30 & 3,44 & 0,88 & & & \\
\hline & Muhasebe & 26 & 3,38 & 0,77 & & & \\
\hline & Güvenlik & 17 & 3,62 & 0,78 & & & \\
\hline & $\begin{array}{l}\text { Genel } \\
\text { Müdürlük/Yönetim }\end{array}$ & 10 & 3,30 & 1,32 & & & \\
\hline & Diğer İse Belirtiniz & 53 & 3,56 & 0,65 & & & \\
\hline \multirow{10}{*}{$\begin{array}{l}\text { Duygulardan } \\
\text { Faydalanma }\end{array}$} & Servis & 116 & 2,62 & 0,76 & \multirow{10}{*}{1,684} & \multirow{10}{*}{,090 } & \\
\hline & Mutfak & 134 & 2,75 & 0,82 & & & \\
\hline & Ön Büro & 59 & 2,78 & 0,87 & & & \\
\hline & Kat Hizmetleri & 116 & 2,76 & 1,03 & & & \\
\hline & Animasyon & 22 & 3,27 & 0,98 & & & \\
\hline & Misafir İlişkileri & 30 & 2,67 & 1,04 & & & \\
\hline & Muhasebe & 26 & 2,74 & 0,95 & & & \\
\hline & Güvenlik & 17 & 3,09 & 0,64 & & & \\
\hline & $\begin{array}{l}\text { Genel } \\
\text { Müdürlük/Yönetim }\end{array}$ & 10 & 3,17 & 1,25 & & & \\
\hline & Diğer İse Belirtiniz & 53 & 2,78 & 0,67 & & & \\
\hline \multirow{3}{*}{ Duyguların İfadesi } & Servis & 116 & 2,83 & 0,57 & \multirow{3}{*}{3,527} & \multirow{3}{*}{, $000^{*}$} & $1<9$ \\
\hline & Mutfak & 134 & 2,83 & 0,56 & & & $2<9$ \\
\hline & Ön Büro & 59 & 3,14 & 0,81 & & & \\
\hline
\end{tabular}


H. D. Sevin - A. Uygur - M. B. Koyuncu 12/3 (2020) 2611-2628

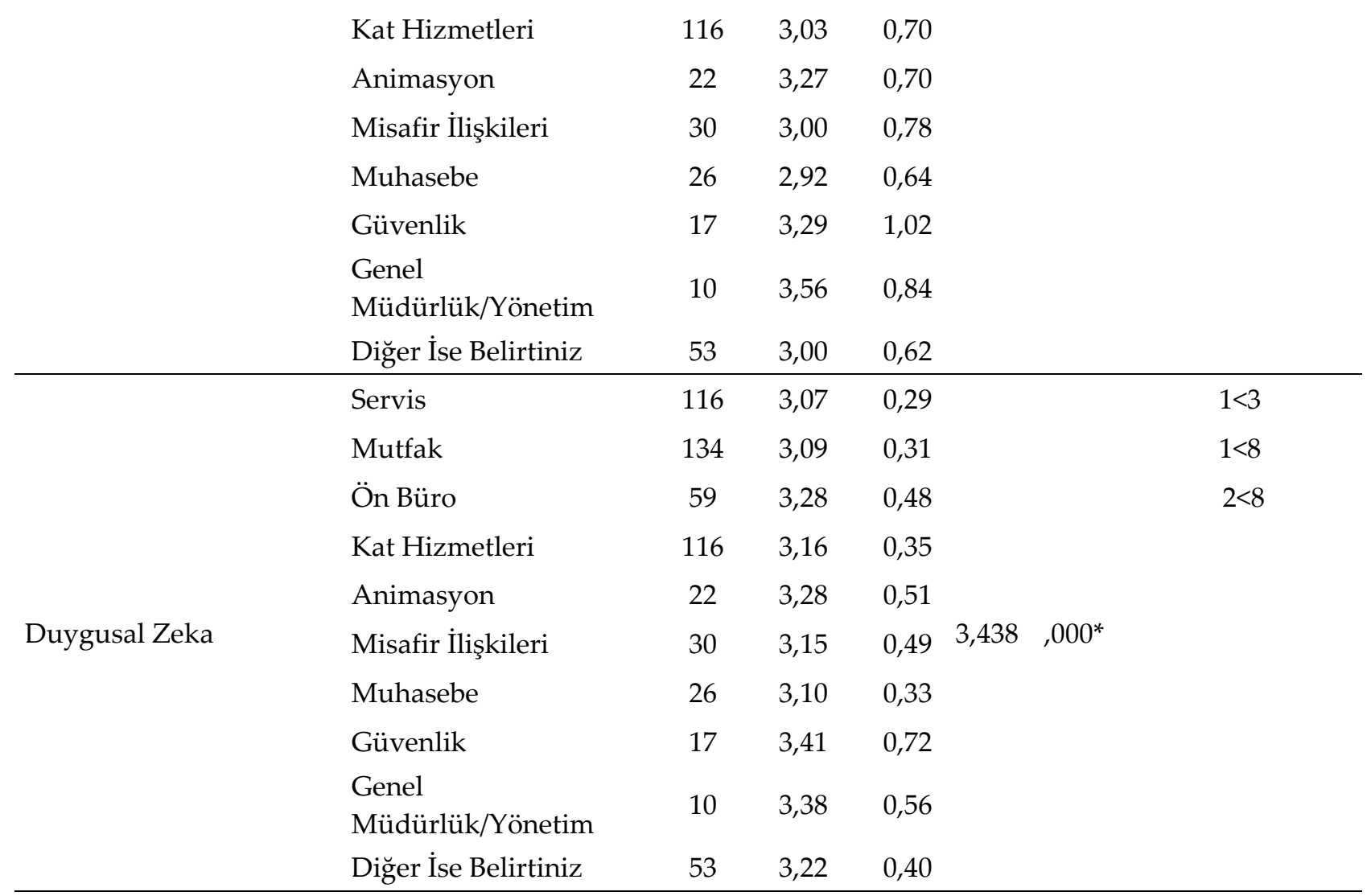

${ }^{*} \mathrm{p}<0,05$

Duygusal Zekanın Çalışılan Bölüm/Departman Açısından İncelenmesi için yapılan ANOVA testi sonuçlarına göre; Çalıştığı bölüm/departman faklı olan gruplar arasında Duyguların İfadesi açısından istatistiksel olarak anlamlı farklılık bulunmaktadır ( $\mathrm{p}<0,05)$. Çalıştı̆̆ bölüm/departman servis olanların ortalaması 2,83; mutfak olanların ortalaması 2,83; ön büro olanların ortalaması 3,14; kat hizmetleri olanların ortalaması 3,03; animasyon olanların ortalaması 3,27; misafir ilişkileri olanların ortalaması 3,00; muhasebe olanların ortalaması'2,92; güvenlik olanların ortalaması 3,29; genel müdürlük/yönetim olanların ortalaması 3,56; diğer olanların ortalaması 3,00'tür. Buna göre Genel Müdürlük/Yönetimde çalışanların Duyguların İfadesi puan ortalaması en büyük iken servis ya da mutfakta çalışanların ortalaması en küçüktür.

Çalıştığı bölüm/departman faklı olan gruplar arasında Duygusal Zeka açısından istatistiksel olarak anlamlı farklılık bulunmaktadır ( $\mathrm{p}<0,05)$. Çalıştığı bölüm/departman servis olanların ortalaması 3,07; mutfak olanların ortalaması 3,09; ön büro olanların ortalaması 3,28; kat hizmetleri olanların ortalaması 3,16; animasyon olanların ortalaması 3,28; misafir ilişkileri olanların ortalaması 3,15; muhasebe olanların ortalaması 3,10; güvenlik olanların ortalaması 3,41; genel müdürlük/yönetim olanların ortalaması 3,38; diğer olanların ortalaması 3,22'dir. Buna göre güvenlik olarak çalışanların Duygusal Zeka puan ortalaması en büyük iken serviste çalışanların ortalaması en küçüktür.

Tablo 11. Duygusal Zekanın Aynı İşletmede/İşletme Grubunda Çalışma Süresi Açısından İncelenmesi

\begin{tabular}{|c|c|c|c|c|c|c|c|}
\hline \multicolumn{2}{|c|}{$\begin{array}{l}\text { Kaç Yıldır Bu İşletmede/İşletme Grubunda } \\
\text { Çalışıyorsunuz }\end{array}$} & $\mathrm{n}$ & Ortalama & ss & $\mathrm{F}$ & $\mathrm{p}$ & Çoklu karşılaştırma \\
\hline \multirow{4}{*}{ İyimserlik } & 1 Yil ve Daha Az & 183 & 3,61 & 0,76 & \multirow{4}{*}{3,945} & \multirow{4}{*}{, $008^{*}$} & \multirow{4}{*}{$1>2$} \\
\hline & 2-4 Yil & 254 & 3,39 & 0,78 & & & \\
\hline & $5-7 Y_{11}$ & 106 & 3,37 & 0,71 & & & \\
\hline & $8 Y_{1} l$ ve üzeri & 40 & 3,28 & 0,95 & & & \\
\hline \multirow{3}{*}{ Duygulardan Faydalanma } & 1 Yil ve Daha Az & 183 & 2,70 & 0,85 & \multirow{3}{*}{1,293} & \multirow{3}{*}{276} & \\
\hline & 2-4 Yil & 254 & 2,75 & 0,88 & & & \\
\hline & $5-7 Y_{11}$ & 106 & 2,83 & 0,89 & & & \\
\hline
\end{tabular}


H. D. Sevin - A. Uygur - M. B. Koyuncu 12/3 (2020) 2611-2628

\begin{tabular}{|c|c|c|c|c|c|c|c|}
\hline & 8 Yıl ve üzeri & 40 & 2,98 & 1,00 & & & \\
\hline \multirow{4}{*}{ Duyguların İfadesi } & 1 Yil ve Daha $A z$ & 183 & 3,03 & 0,77 & \multirow{4}{*}{1,199} & \multirow{4}{*}{310} & \\
\hline & 2-4 Yil & 254 & 2,93 & 0,59 & & & \\
\hline & 5-7 Yil & 106 & 2,94 & 0,66 & & & \\
\hline & 8 Yıl ve üzeri & 40 & 3,08 & 0,80 & & & \\
\hline \multirow{4}{*}{ Duygusal Zeka } & 1 Yil ve Daha Az & 183 & 3,24 & 0,48 & \multirow{4}{*}{4,353} & \multirow{4}{*}{, $005^{*}$} & \multirow{4}{*}{$1>2$} \\
\hline & 2-4 Yil & 254 & 3,11 & 0,31 & & & \\
\hline & 5-7 Yil & 106 & 3,12 & 0,35 & & & \\
\hline & 8 Yil ve üzeri & 40 & 3,15 & 0,42 & & & \\
\hline
\end{tabular}

${ }^{*} \mathrm{p}<0,05$

Duygusal Zekanın Aynı İşletmede/İşletme Grubunda Çalışma Süresi Açısından İncelenmesi için yapılan ANOVA testi sonuçlarına göre;

Aynı işletmede/işletme grubundaki çalışma süresi faklı olan gruplar arasında İyimserlik açısından istatistiksel olarak anlamlı farklılık bulunmaktadır $(\mathrm{p}<0,05)$. 1 yıl ve daha az süredir çalışanların ortalaması 3,61; 2-4 yıldır çalışanların ortalaması 3,39; 5-7 yıldır çalışanların ortalaması 3,37; 8 yıl ve daha fazla süredir çalışanların ortalaması 3,28' dir. Buna göre Aynı işletmede/işletme grubunda 1 yıl ve daha az süredir çalışanların İyimserlik puan ortalaması en büyük iken süre arttıkça ortalama azalmaktadır.

Aynı işletmede/işletme grubundaki çalışma süresi faklı olan gruplar arasında Duygusal Zeka açısından istatistiksel olarak anlamlı farklılık bulunmaktadır $(\mathrm{p}<0,05) .1$ yıl ve daha az süredir çalışanların ortalaması 3,24; 2-4 yıldır çalışanların ortalaması 3,11; 5-7 yıldır çalışanların ortalaması 3,12; 8 yıl ve daha fazla süredir çalışanların ortalaması 3,15'tir. Buna göre aynı işletmede/işletme grubunda 1 yıl ve daha az süredir çalışanların Duygusal Zeka puan ortalaması en büyük iken 2-4 yıldır çalışanların ortalaması en küçüktür.

Tablo 12. Duygusal Zekanın Turizm Sektöründe Çalışma Süresi Açısından İncelenmesi

\begin{tabular}{|c|c|c|c|c|c|c|c|}
\hline \multicolumn{2}{|c|}{ Kaç Yıldır Turizm Sektöründe Çalışıyorsunuz } & \multirow{2}{*}{$\frac{\mathrm{n}}{103}$} & \multirow{2}{*}{$\begin{array}{c}\text { Ortalama } \\
3,53\end{array}$} & \multirow{2}{*}{$\begin{array}{c}\text { ss } \\
0,79\end{array}$} & \multirow[t]{2}{*}{$\mathrm{F}$} & \multirow[t]{2}{*}{$\mathrm{p}$} & Çoklu karşılaştırma \\
\hline \multirow{5}{*}{ İyimserlik } & 1 Yıl ve Daha Az & & & & & & \\
\hline & 2-4 Yil & 213 & 3,35 & 0,80 & \multirow{4}{*}{1,434} & \multirow{4}{*}{221} & \\
\hline & $5-7 Y_{11}$ & 150 & 3,50 & 0,70 & & & \\
\hline & 8-10 Yil & 65 & 3,53 & 0,69 & & & \\
\hline & 11 Yil ve Üzeri & 52 & 3,44 & 0,97 & & & \\
\hline \multirow{5}{*}{ Duygulardan Faydalanma } & $1 Y_{1}$ l ve Daha $A z$ & 103 & 2,70 & 0,95 & \multirow{5}{*}{1,878} & \multirow{5}{*}{113} & \\
\hline & 2-4 Yil & 213 & 2,82 & 0,86 & & & \\
\hline & $5-7$ Yil & 150 & 2,63 & 0,84 & & & \\
\hline & 8-10 Y1l & 65 & 2,83 & 0,80 & & & \\
\hline & 11 Yıl ve Üzeri & 52 & 2,94 & 1,00 & & & \\
\hline \multirow{5}{*}{ Duyguların İfadesi } & 1 Yil ve Daha $A z$ & 103 & 2,92 & 0,71 & \multirow{5}{*}{2,482} & \multirow{5}{*}{, $043^{*}$} & \multirow{5}{*}{$3<5$} \\
\hline & 2-4 Y 11 & 213 & 3,00 & 0,62 & & & \\
\hline & 5-7 Yil & 150 & 2,88 & 0,70 & & & \\
\hline & 8-10 Yil & 65 & 3,00 & 0,66 & & & \\
\hline & 11 Y1l ve Üzeri & 52 & 3,20 & 0,73 & & & \\
\hline \multirow{5}{*}{ Duygusal Zeka } & 1 Yil ve Daha Az & 103 & 3,17 & 0,40 & \multirow{5}{*}{1,993} & \multirow{5}{*}{,094 } & \\
\hline & 2-4 Yil & 213 & 3,13 & 0,38 & & & \\
\hline & 5-7 Yil & 150 & 3,12 & 0,36 & & & \\
\hline & 8-10 Y 11 & 65 & 3,21 & 0,41 & & & \\
\hline & 11 Yil ve Üzeri & 52 & 3,27 & 0,46 & & & \\
\hline
\end{tabular}

${ }^{*} \mathrm{p}<0,05$ 
H. D. Sevin - A. Uygur - M. B. Koyuncu 12/3 (2020) 2611-2628

Duygusal Zekanın Turizm Sektöründe Çalışma Süresi Açısından İncelenmesi için yapılan ANOVA testi sonuçlarına göre; Turizm sektöründeki çalışma süresi faklı olan gruplar arasında Duyguların İfadesi açısından istatistiksel olarak anlamlı farklılık bulunmaktadır $(\mathrm{p}<0,05) .1$ yıl ve daha az süredir çalışanların ortalaması 2,92; 2-4 yıldır çalışanların ortalaması 3,00; 5-7 yıldır çalışanların ortalaması 2,88; 8-10 yıldır çalışanların ortalaması 3,00; 11 yıl ve daha fazla süredir çalışanların ortalaması 3,20'dir. Buna göre turizm sektöründe 11 yıl ve daha fazla süredir çalışanların Duyguların İfadesi puan ortalaması en büyük iken 5-7 yıldır çalışanların ortalaması en küçüktür.

Tablo 13. Duygusal Zekanın Çalışanın Uyruk Açısından İncelenmesi

\begin{tabular}{llccccc}
\hline A.11. Uyruğunuz? & & $\mathrm{n}$ & Ortalama & $\mathrm{ss}$ & $\mathrm{t}$ & $\mathrm{p}$ \\
\hline \multirow{2}{*}{ İyimserlik } & Türkiye Cumhuriyeti & 523 & 3,46 & 0,76 & \multirow{2}{*}{, 932} & \multirow{2}{*}{, 352} \\
& Yabancı Uyruklu & 60 & 3,36 & 0,98 & & \\
\hline \multirow{2}{*}{ Duygulardan Faydalanma } & Türkiye Cumhuriyeti & 523 & 2,75 & 0,86 & \multirow{2}{*}{ ( 24,169} & \multirow{2}{*}{, 243} \\
& Yabancı Uyruklu & 60 & 2,89 & 1,07 & & \\
\hline \multirow{2}{*}{ Duyguların İfadesi } & Türkiye Cumhuriyeti & 523 & 2,97 & 0,67 & \multirow{2}{*}{, 587} & \multirow{2}{*}{, 558} \\
& Yabancı Uyruklu & 60 & 3,02 & 0,74 & & \\
\hline \multirow{2}{*}{ Duygusal Zeka } & Türkiye Cumhuriyeti & 523 & 3,16 & 0,38 & \multirow{2}{*}{, 043} & \multirow{2}{*}{, 965} \\
& Yabancı Uyruklu & 60 & 3,15 & 0,44 & & \\
\hline
\end{tabular}

${ }^{*} \mathrm{p}<0,05$

Duygusal Zekanın Çalışanın Uyruğu Açısından İncelenmesi için yapılan t testi sonuçları göre; Türk ile yabancı çalışanlar arasında Duygusal Zeka boyutları açısından istatistiksel olarak anlamlı farklılık bulunmamaktadır $(\mathrm{p}>0,05)$.

Tablo 14. Duygusal Zekanın Çalışanın Çocukluğunu Geçirildiği Yer Açısından İncelenmesi

\begin{tabular}{|c|c|c|c|c|c|c|}
\hline Çocukluğunuzu Geçirdiğiniz Yer & & $\mathrm{n}$ & Ortalama & ss & $\mathrm{F}$ & $\mathrm{p}$ \\
\hline \multirow{3}{*}{ İyimserlik } & Köy-Belde & 135 & 3,45 & 0,75 & \multirow{3}{*}{ 637 } & \multirow{3}{*}{, 529} \\
\hline & İlçe & 217 & 3,49 & 0,73 & & \\
\hline & İl & 231 & 3,41 & 0,84 & & \\
\hline \multirow{3}{*}{ Duygulardan Faydalanma } & Köy-Belde & 135 & 2,79 & 0,88 & \multirow{3}{*}{,981 } & \multirow{3}{*}{,375 } \\
\hline & İlçe & 217 & 2,70 & 0,87 & & \\
\hline & İl & 231 & 2,81 & 0,90 & & \\
\hline \multirow{3}{*}{ Duyguların İfadesi } & Köy-Belde & 135 & 2,99 & 0,68 & \multirow{3}{*}{1,462} & \multirow{3}{*}{233} \\
\hline & İlçe & 217 & 2,91 & 0,68 & & \\
\hline & İl & 231 & 3,02 & 0,67 & & \\
\hline \multirow{3}{*}{ Duygusal Zeka } & Köy-Belde & 135 & 3,17 & 0,42 & \multirow{3}{*}{245} & \multirow{3}{*}{ 782 } \\
\hline & İlçe & 217 & 3,14 & 0,40 & & \\
\hline & İl & 231 & 3,16 & 0,37 & & \\
\hline
\end{tabular}

${ }^{*} \mathrm{p}<0,05$

Duygusal Zekanın Çocukluğun Geçirildiği Yer Açısından İncelenmesi için yapılan ANOVA testi sonuçlarına göre; Çocukluğunu geçirdiği yer farklı olan gruplar arasında Duygusal Zeka boyutları açısından istatistiksel olarak anlamlı farklılık bulunmamaktadır $(\mathrm{p}>0,05)$. 
H. D. Sevin - A. Uygur - M. B. Koyuncu 12/3 (2020) 2611-2628

Tablo 15. Duygusal Zekanın Günlük Çalışma Süresi Açısından İncelenmesi

\begin{tabular}{llcccccc}
\hline Günde Kaç Saat Çalışıorsunuz & $\mathrm{n}$ & Ortalama & $\mathrm{ss}$ & $\mathrm{F}$ & $\mathrm{p}$ & Çoklu karşılaştırma \\
\hline \multirow{4}{*}{ İyimserlik } & 8 Saatten Az & 35 & 3,44 & 0,87 & & & \\
& 8 Saat & 417 & 3,47 & 0,79 &, 490 &, 613 & \\
& 8 Saatten Fazla & 131 & 3,39 & 0,74 & & & \\
\hline \multirow{4}{*}{ Duygulardan Faydalanma } & 8 Saatten Az & 35 & 2,88 & 0,98 & & &, 314 \\
& 8 Saat & 417 & 2,73 & 0,90 & 1,161 & \\
& 8 Saatten Fazla & 131 & 2,84 & 0,80 & & & \\
\hline \multirow{4}{*}{ Duyguların İfadesi } & 8 Saatten Az & 35 & 3,10 & 0,76 & & & \\
& 8 Saat & 417 & 2,93 & 0,67 & 3,628 &, 027 & \\
\hline & 8 Saatten Fazla & 131 & 3,09 & 0,66 & & & \\
\hline \multirow{2}{*}{ Duygusal Zeka } & 8 Saatten Az & 35 & 3,22 & 0,41 & & & \\
& 8 Saat & 417 & 3,14 & 0,38 & 1,138 &, 321 & \\
& 8 Saatten Fazla & 131 & 3,19 & 0,42 & & & \\
\hline
\end{tabular}

${ }^{*} \mathrm{p}<0,05$

Duygusal Zekanın Günlük Çalışma Süresi Açısından İncelenmesi için yapılan ANOVA testi sonuçlarına göre; Günlük çalışma süresi faklı olan gruplar arasında Duyguların İfadesi açısından istatistiksel olarak anlamlı farklılık bulunmaktadır ( $\mathrm{p}<0,05)$. 8 saatten az çalışanların ortalaması 3,10; 8 saat çalışanların ortalaması 2,93; 8 saatten fazla çalışanların ortalaması 3,09'dur. Buna göre günlük 8 saatten az çalışanların Duyguların İfadesi puan ortalaması en büyük iken 8 saat çalışanların ortalaması en küçüktür.

Tablo 16. Duygusal Zekanın Mesleğini İsteyerek Seçme Durumu Açısından İncelenmesi

\begin{tabular}{|c|c|c|c|c|c|c|}
\hline A.14. Mesleğinizi İsteyerek mi Seçtiniz? & & $\mathrm{n}$ & Ortalama & ss & $\mathrm{t}$ & $\mathrm{p}$ \\
\hline \multirow{2}{*}{ İyimserlik } & Evet & 425 & 3,48 & 0,80 & \multirow{2}{*}{1,750} & \multirow{2}{*}{,081 } \\
\hline & Hayır & 158 & 3,36 & 0,72 & & \\
\hline \multirow{2}{*}{ Duygulardan Faydalanma } & Evet & 425 & 2,76 & 0,90 & \multirow{2}{*}{$-0,170$} & \multirow{2}{*}{,865 } \\
\hline & Hayır & 158 & 2,77 & 0,84 & & \\
\hline \multirow{2}{*}{ Duyguların İfadesi } & Evet & 425 & 2,97 & 0,71 & \multirow{2}{*}{0,047} & \multirow{2}{*}{,962 } \\
\hline & Hayır & 158 & 2,97 & 0,60 & & \\
\hline \multirow{2}{*}{ Duygusal Zeka } & Evet & 425 & 3,17 & 0,41 & \multirow{2}{*}{1,771} & \multirow{2}{*}{077} \\
\hline & Hayır & 158 & 3,12 & 0,32 & & \\
\hline
\end{tabular}

${ }^{*} \mathrm{p}<0,05$

Duygusal Zekanın Mesleğini İsteyerek Seçme Durumu Açısından İncelenmesi için yapılan $\mathrm{t}$ testi sonuçlarına göre; Mesleğini isteyerek seçme durumu farklı olan gruplar arasında Duygusal Zeka boyutları açısından istatistiksel olarak anlamlı farklılık bulunmamaktadır $(\mathrm{p}>0,05)$.

\section{Sonuç ve Öneriler}

$\mathrm{Bu}$ araştırmanın amacı Turizm İşletmelerinden biri olan otel çalışanlarının demografik özelliklere göre duygusal zeka(EI) düzeylerinin farklılık gösterip, göstermediğinin tespit edilmesidir. Araştırmada elde edilen bulgular şöyle özetlenebilir;

Demografik özelliklerden, cinsiyet, medeni durum, öğrenim durumu, aylık gelir, ailenin toplam geliri, uyruğun Türk veya yabancı olması, çocukluğun geçirdiği yerin farklı olması, meslek seçimi ile duygusal zeka boyutları açısından istatistiksel olarak anlamlı farklılık bulunamamıştır. Bu sonuçla ilişki olarak benzer bir çalışmada, cinsiyet, medeni durum ile duygusal zekâ düzeyleri açıdan farklılık bulunamamıştır(Akbolat ve Işık,2012:119). 
H. D. Sevin - A. Uygur - M. B. Koyuncu 12/3 (2020) 2611-2628

Duygusal zeka düzeyi yaş açısından incelendiğinde, duyguların ifadesi açısından istatistiksel olarak anlamlı farklılık bulunmuştur. Duygusal Zeka düzeyi ile işletmedeki statüsü faklı olan gruplar arasında duyguların ifadesi, duygulardan faydalanma ve duygusal zeka açısından istatistiksel olarak anlamlı farklılık bulunmuştur. Buna göre Departman Müdür Yrd/Asistanı-Kısım Şefi-Şef ya da Departman Müdürü/Genel Müdür/Otel Müdürü olanların Duygusal Zeka puan ortalaması en büyük iken Departman Çalışanı olanların ortalaması en küçüktür. Arslan(2013) vd. tarafından hizmet sektörü çalışanlarına yönelik yapılan çalışmada yöneticilerin duygusal zekâ düzeylerinin yüksek olduğunu tespit edilmiştir(Arslan vd,2013:114).

Duygusal zeka ile işletmede/işletme grubunda çalışma süresi açısından istatistiksel olarak anlamlı farklılık bulunmuştur. Çalıştığı bölüm/departman faklı olan gruplar arasında Duygusal Zeka açısından istatistiksel olarak anlamlı farklılık bulunmuştur. Turizm sektöründeki çalışma süresi faklı olan gruplar arasında, Duyguların İfadesi açısından istatistiksel olarak anlamlı farklılık bulunmuştur.

Turizm işletmelerinden otel çalışanları üzerinde gerçekleştirilen bu çalışmada, çalışanların statüleri arttıkça duygusal zeka puanlarının arttı̆̆ı, diğer bir ifadeyle yönetim düzeyinde çalışanların duygusal zeka puanları yüksek olduğu saptanmıştır. Ayrıca Bölüm/departman faklı olan gruplar arasında Duygusal Zeka açısından istatistiksel olarak anlamlı farklılık bulunmuştur.

Bir çok araştırma, yönetici kademesinde olanların duygusal zeka düzeyinin örgütlerin işleyişi açısından önemli olduğu ve yöneticilere yönelik eğitim programların da bu unsurun geliştirilmesi gerektiğini vurgulamaktadır(Babaoğlan,2010:132).

İşletmede çalışanlar arasında uyum, etkili iletişim, motivasyon ve empatinin geliştirilmesinde sosyal zekanın bir boyutu olan duygusal zeka oldukça önemlidir. İşletmelerde çalışanların duygusal zeka düzeylerinin geliştirilmesi için gerekli çalışmaların yapılması gerekmektedir. Literatürde duygusal zekanın kalıtsal olmadığı öğrenebileceği ve geliştirilebileceği ortak görüşü söz konusudur(Akbolat ve Işık,2012:120).

Sonuç olarak bu çalışmanın bulguları seçilen örneklem grubunla sınırlı olup, genellenebilir olmamakla birlikte, araştırma farklı niteliklere sahip örneklem gruplarında incelenmesi literatüre katkı açısından faydalı olacaktır.

\section{KAYNAKÇA}

Akbolat, M. ve Işık, O. (2012). Sağlık Çalışanlarının Duygusal Zekâ Düzeylerinin Motivasyonlarına Etkisi, DPUJSS NUMBER 32, VOL. I, APRIL., https://dergipark.org.tr/tr/download/article-file/55753.

Arslan, R., Efe D. ve Aydın E.(2013). Duygusal Zeka Ve Örgütsel Bağlılık Arasındaki İlişki: Sağlık Çalışanları Üzerinde Bir Araştırma, Uluslararası Alanya İşletme Fakültesi Dergisi, Y1l:2013, 5,(3), 169-180.

Arslan, R., Mazan, İ. ve Aydın, E. (2013). Yönetimde Değişen Duygu Zekâ İlişkisi ve Yöneticilerin Duygusal Zekâ Düzeylerine İlişkin Bir Araştırma, Uşak Üniversitesi Sosyal Bilimler Dergisi, 6/3,99-116.

Babaoğlan, E.(2010). Okul Yöneticilerinde Duygusal Zekâ, Ahi Evran Üniversitesi Eğitim Fakültesi Dergisi, Cilt 11,Sayı 1, Nisan, 119-136.

Çelenk, İ. (2015). Örgütlerde Duygusal Zekâ Ve Psikolojik Yıldırma: Bir Araştırma, Pamukkale Üniversitesi, Sosyal Bilimler Enstitüsü, İşletme Ana Bilim Dalı, Yönetim Ve Organizasyon Programı, Yüksek Lisans Tezi, Eylül, Denizli.

Doğan, S ve Şahin, F. (2007). Duygusal Zekâ: Tarihsel Gelişimi ve Örgütler İçin Önemine Kavramsal Bir Bakış, Ç.Ü. Sosyal Bilimler Enstitüsü Dergisi, Cilt 16, Sayı 1, 231-252.

Eröz, S., S.(2013). Örgütlerde Duygusal Zeka, Balıkesir Üniversitesi Sosyal Bilimler Enstitüsü Dergisi, Volume: 16 - Number: 29, June,213-242.

Eröz, S., S.(2011). Duygusal Zeka ve İletişim Arasındaki İlişki: Bir Uygulama, T. C. Uludağ Üniversitesi Sosyal Bilimler Enstitüsü, İşletme Anabilim Dalı, Yönetim ve Organizasyon Bilim Dalı, Doktora Tezi, Bursa.

Genç, G. , Genç, V. ve Gümüş, M. (2016). Otel İşletmelerinde Duygusal Zekanın İş Stresi ve İş Yaşam Dengesi Üzerindeki Etkisi, Batman Üniversitesi, Yaşam Bilimleri Dergisi, Cilt 6 Sayı 2/1, 97-112. 
H. D. Sevin - A. Uygur - M. B. Koyuncu 12/3 (2020) 2611-2628

Göçet, E.(2006 ). Üniversite Öğrencilerinin Duygusal Zeka Düzeyleri İle Stresle Başa Çıkma Tutumları Arasındaki İlişki, Sakarya Üniversitesi, Sosyal Bilimler Enstitüsü, Y.L.Tezi, Sakarya.

Gökhan, B.(2011). Çoklu Zekâ Kuramında Bir Adım Daha: Ekolojik Zekâ". Ekolojik Zekâ, Bilim ve Aklın Aydınlığında Eğitim, S:134, Nisan, 2011,7-10.

Güllüce, A., Ç. ve İşcan, Ö., F.(2010). Mesleki Tükenmişlik ve Duygusal Zeka Arasındaki İlişki, Eskişehir Osmangazi Üniversitesi, İ̈BF, Dergisi, Ekim, 5(2), 7-29.

Gürbüz, S. ve Yüksel, M. (2008). Çalışma Ortamında Duygusal Zeka: İş Performansı, İş Tatmini, Örgütsel Vatandaşlık Davranışı ve Bazı Demografik Özelliklerle İlişkisi, Doğuş Üniversitesi Dergisi, 9 (2), 174 190.

Gürel, E. ve Tat M.(2010). Çoklu Zekâ Kuramı: Tekli Zekâ Anlayışından Çoklu Zekâ Yaklaşımına. Uluslararası Sosyal Ara tırmalar Dergisi, The Journal of International Social Research, Volume 3 / 11 Spring,336356.

Konakay, G. (2013). Akademisyenlerde Duygusal Zekâ Faktörlerinin Tükenmişlik Faktörleri İle İlişkisine Yönelik Bir Araştırma, Kocaeli Üniversitesi Örneği, Dokuz Eylül Üniversitesi, Sosyal Bilimler Enstitüsü Dergisi, Cilt: 15, Sayı: 1, 121-144.

Özdamar, K.(2004). Paket Programlar İle İstatistiksel Veri Analizi 1, Genişletilmiş Baskı, Kaan Kitapevi.

Pelit, E. ve Ayana Ç.(2016). Duygusal Zekânın Örgütsel Sinizme Etkisi: Otel İşletmeleri İşgörenleri Üzerinde Bir Araştırma, İşletme Araştırmaları Dergisi, 8/2, 45-76.

Polatcı, S. ve Özyer K.(2015). Duygusal Emek Stratejilerinin Duygusal Zekanın Tükenmişliğe Etkisindeki Aracılık Rolü, AİBÜ, Sosyal Bilimler Enstitüsü Dergisi, Cilt:15, Yıl:15, Sayı:3, 131-156.

Roberts R. D. ve Barsade, S. (2008). Human Abilities: Emotional Intelligence, Annu. Rev. Psychol, 59:507-36.

Scott, S -, B.A., B.S., H., M.S. (2006). Emotional Intelligence In The Hospitality Industry: A Comparison Study, A Dissertation In Hospitality Administration, Submitted To The Graduate Faculty Of Texas Tech University In Partial Fulfillment Of The Requirements For The Degree Of Doctor Of Philosophy, Texas.

Shahhosseini, M., Silong, A. D. ve Ismaill, I., A.(2013). Relatıonshıp Between Transactıonal, Transformatıonal Leadership Styles, Emotional Intelligence And Job Performance, Researchers World -Journal Of Arts, Science \& Commerce, International Refereed Research Journal, Vol.-IV, Issue-1(1), January(15),15-22.

Sevin, H., D. ve Özil, L. (2019). The Relationship Between Teachers' Level Of Participation In Recreation Activities And Emotional Intelligence And Life Satisfaction, Journal Of Tourism And Gastronomy Studies 7/3, 2038-2065.

Şahin, N. H., Güler, M.ve Basım, N.(2009). A Tipi Kişilik Örüntüsünde Bilişsel ve Duygusal Zekânın Stresle Başa Çıkma ve Stres Belirtileri İle İlişkisi, Türk Psikiyatri Dergisi, 20(3):243-254.

Turhan, M. ve Çetinsöz, B. C. (2019). Duygusal Zekâ ve Motivasyon Arasındaki İlişki: Turizm Programı Öğrencileri Üzerine Bir Araştırma, Elektronik Sosyal Bilimler Dergisi, Kış, Cilt:18, Sayı:69, 268-287.

Türk Dil Kurumu: http://Tdk.Gov.Tr,(21.4.2020).

Ural, A.(2001). Yöneticilerde Duygusal Zekanın Üç Boyutu, Dokuz Eylül Üniversitesi Sosyal Bilimler Enstitüsü Dergisi, Cilt 3, Sayı:2, 209-219.

Yelkikalan, N.(2006). 21. Yüzyılda Girişimcinin Yeni Özelliği: Duygusal Zeka, 39-59, http://Acikerisim.Lib.Comu.Edu.Tr:8080/Xmlui/Handle/Comu/979, (15.4.2020).

Yılmaz, C., Fidan, Y. ve Yıldıran, C. (2014). Duygusal Zeka ve Örgüt İklimine Etkisi, Business \& Management Studies, An International Journal, Vol.2, Issue.3, 243-261. 